\title{
Implementasi Model Pembelajaran Kooperatif Tipe Teams Assisted Individualization (TAI) Pada Siswa Kelas X 3 SMA Negeri 14 Samarinda
}

\author{
Reni Periyanti ${ }^{1 *}$, Muliati Syam ${ }^{2}$ \\ $1^{*}$ Universitas Negeri Malang, Malang \\ 2 Program Studi Pendidikan Fisika Fakultas Keguruan dan IImu Pendidikan \\ Universitas Mulawarman, Samarinda \\ `E-mail Penulis Korespondensi: reniperiyanti1994@gmail.com
}

\begin{abstract}
Abstrak
Pembelajaran kooperatif tipe Teams Assisted Individualization (TAI) merupakan pembelajaran yang melibatkan siswa dalam pemecahan masalah yang diberikan oleh guru dalam kelompok kecil, sehingga siswa dituntut untuk berpartisipasi secara aktif di dalam kelas. Jenis penelitian yang digunakan adalah Penelitian Tindakan Kelas (PTK) model Kemmis dan Mc Taggart. Subjek penelitian adalah 27 siswa kelas X-3 SMAN 14 Samarinda. Penelitian ini dilaksanakan di semester genap tahun ajaran 2015/2016 dalam dua siklus pembelajaran pada materi optika geometris. Teknik pengumpulan data dengan cara pemberian pretest-posttest, observasi dan dokumentasi. Hasil penelitian menunjukkan ketuntasan hasil belajar siswa meningkat dari $51,85 \%$ menjadi $81,84 \%$ dan persentase aktivitas belajar siswa selama proses pembelajaran sebesar $93,11 \%$ dengan kriteria sangat baik. Hal tersebut menunjukkan bahwa model pembelajaran kooperatif tipe TAI dapat meningkatkan hasil belajar dan aktivitas siswa kelas X-3 SMA Negeri 14 Samarinda.
\end{abstract}

Kata kunci: Pembelajaran kooperatif, team assisted individualization, hasil belajar, aktivitas siswa.

\section{Abstract}

Teams Assisted Individualization (TAI) of cooperative learning is a type of education that involves students in solving problems given by the teacher in small groups. In this learning, students require to participate actively in the classroom. This type of research is the Classroom Action Research (PTK) model of Kemmis and Mc Taggart. The research subjects were 27 students of class X-3 at SMAN 14 Samarinda. This research was conducted in the even semester of the 2015/2016 academic year in two learning cycles on geometric optics. Data collection techniques by giving pretest-posttest, observation and documentation. The results showed that the completeness of student learning outcomes increased from $51.85 \%$ to $81.84 \%$ and the percentage of student learning activities during the learning process was $93.11 \%$ with very good criteria. This shows that the cooperative learning model type TAl can improve learning outcomes and student activities in class X-3 SMA Negeri 14 Samarinda.

Keywords: Cooperative learning, teams assisted individualization, learning outcome, student activity.

Article History: Received: 12 Maret 2021

Accepted: 21 Maret 2021
Revised : 1 April 2021

Published: 30 April 2021

How to cite: Periyanti, R. \& Syam, M. (2021). Implementasi Model Pembelajaran Kooperatif Tipe Teams Assisted Individualization (TAI) Pada Siswa Kelas X 3 SMA Negeri 14 Samarinda, Jurnal Literasi Pendidikan Fisika, 2 (1). pp. 92-98. Retrieved from http://jurnal.fkip.unmul.ac.id/index.php/JLPF

Copyright @ April 2021, Jurnal Literasi Pendidikan Fisika 
Implementasi Model Pembelajaran...

\section{PENDAHULUAN}

Penilaian pembelajaran fisika tidak hanya diperoleh semata-mata dari hasil tes, melainkan juga pada proses kegiatan belajar mengajar. Sasaran penilaian mencakup tiga sasaran pokok, yakni program pendidikan, proses belajar mengajar dan hasil-hasil belajar (Sudjana, 2009). Penilaian terhadap proses belajar mengajar salah satunya adalah aktivitas siswa, yaitu aktivitas yang dapat membawa perubahan ke arah yang lebih baik pada diri siswa karena adanya interaksi antara siswa dengan siswa, siswa dengan guru, maupun siswa dengan lingkungan sekitar (Ningsih et al., 2017). Hasil belajar dapat diperoleh dari pelaksanaan tes yang diberikan kepada siswa pada akhir kegiatan belajar mengajar. Sehingga dapat dikatakan bahwa apabila pelaksanaan penilaian siswa dilakukan dengan baik, maka tujuan pembelajaran dapat dicapai secara optimal (Megawati \& Sari, 2012).

Terdapat dua faktor utama yang mempengaruhi hasil belajar yaitu faktor dari dalam diri siswa itu sendiri seperti kemampuan yang dimiliki siswa, motivasi belajar, minat dan perhatian, sikap dan kebiasaan belajar, ketekunan, sosial ekonomi, fisik dan psikis, dan faktor yang datang dari luar diri siswa atau faktor lingkungan seperti kualitas pengajaran (Sudjana, 2010). Metode pembelajaran merupakan salah satu faktor eksternal yang mempengaruhi hasil belajar siswa (Sutrisno \& Siswanto, 2016). Dalam upaya mewujudkan keterlibatan siswa secara aktif dalam proses pembelajaran, guru harus dapat memilih metode dan strategi pembelajaran yang sesuai dalam pembelajaran sehingga tujuan dari pembelajaran dapat tercapai, salah satunya adalah model pembelajaran kooperatif (Vhalery \& Nofriansyah, 2018). Model pembelajaran kooperatif mengacu pada aktivitas pembelajaran kelompok dimana pembelajaran harus didasarkan pada perubahan informasi secara sosial di antara kelompokkelompok siswa yang di dalamnya setiap siswa bertanggung jawab atas pembelajarannya sendiri dan didorong untuk meningkatkan pembelajaran anggota-anggota yang lain (Huda, 2012). Selain itu, dalam sebuah penelitian dinyatakan bahwa penggunaan pembelajaran kooperatif dapat meningkatkan prestasi belajar dan sekaligus dapat meningkatkan hubungan sosial, menumbuhkan sikap toleransi, dan menghargai pendapat orang lain (Slavin, 2011; Rusman, 2011).

Berdasarkan hasil observasi yang telah dilakukan di SMA Negeri 14, diketahui bahwa pembelajaran secara konvensional masih sering dilaksanakan oleh guru sehingga siswa cenderung pasif karena hanya menerima materi, contoh soal dan latihan soal dari guru. Hasil belajar siswa cenderung di bawah Kriteria Ketuntasan Minimum (KKM) yang ditetapkan. Hal ini dikarenakan siswa cenderung menjadi pendengar yang pasif akibat kurangnya keterlibatan secara aktif dalam proses pembelajaran. Berdasarkan hal tersebut, maka diperlukan model pembelajaran yang memungkinkan guru untuk mengajarkan suatu materi kepada siswa dengan menarik.

Salah satu model pembelajaran yang dapat memfasilitasi proses pembelajaran khususnya mata pelajaran fisika adalah model pembelajaran tipe Team Assisted Individualization (TAI) karena pada model ini siswa ditempatkan dalam kelompok-kelompok kecil yang terdiri dari dua atau lebih siswa heterogen untuk saling membantu dalam proses pembelajaran. Model pembelajaran kooperatif tipe TAI lebih menekankan siswa untuk memiliki ketergantungan yang positif, memiliki rasa tanggung jawab, tatap muka pertemuan, komunikasi intensif, dan proses evaluasi kelompok sehingga pengelolaan kelas menjadi lebih efektif. Pembelajaran kooperatif tipe TAI merupakan pembelajaran yang melibatkan siswa dalam pemecahan masalah yang diberikan oleh guru dalam kelompok kecil, sehingga siswa dituntut untuk berpartisipasi secara aktif di dalam kelas (Rudi, 2017). Adapun hasil belajar siswa menjadi lebih baik setelah diterapkan model pembelajaran kooperatif tipe TAl karena siswa terlibat secara aktif dalam proses pembelajaran (Cahyaningsih, 2019; Permatasari, 2012; Mardhiah, 2016). Di sisi lain, siswa juga diajarkan sikap toleransi terhadap perbedaan-perbedaan yang mungkin muncul dalam kelompok. Berdasarkan uraian diatas, maka dilakukan penelitian tentang penerapan model pembelajaran kooperatif tipe TAI pada siswa kelas X-3 SMA Negeri 14 Samarinda. Diharapkan bahwa penerapan model tersebut dapat meningkatkan hasil belajar sekaligus meningkatkan aktivitas siswa selama proses pembelajaran.

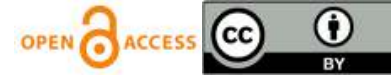


Implementasi Model Pembelajaran...

\section{METODE}

Penelitian ini merupakan penelitian tindakan kelas yang terdiri dari dua siklus. Model penelitian tindakan kelas yang digunakan adalah model Kemmis dan Mc Taggart. Subjek dari penelitian ini adalah siswa kelas X-3 dengan 35 siswa yang terdiri 23 putri dan 12 putra. Objek penelitian ini adalah pembelajaran kooperatif tipe TAl yang diterapkan pada materi optik geometri. Penelitian ini dilaksanakan di SMA Negeri 14 Samarinda yang beralamat di jalan Jakarta, Kelurahan Loa Bakung, Kecamatan Sungai Kunjang, Kota Samarinda.

Pembelajaran kooperatif tipe TAI memiliki langkah-langkah pembelajaran yang dapat mendorong kemampuan siswa dalam memahami materi fisika dan meningkatkan aktivitas siswa dalam pembelajaran. Langkah-langkah tersebut adalah sebagai berikut:

1. Placement Test (Tes Penempatan)

Guru mengumpulkan hasil belajar siswa pada materi sebelumnya (suhu dan kalor) sebagai nilai pretest yang bertujuan untuk mengetahui kelemahan siswa sebelum dilakukan penelitian.

2. Teams (Tim)

Guru mengelompokkan siswa ke dalam beberapa kelompok heterogen yang terdiri dari 4-5 siswa untuk masing-masing kelompok.

3. Teaching Group (Pengajaran Kelompok)

Guru menjelaskan secara singkat materi pelajaran sebelum memberikan tugas.

4. Student Creative (Mahasiswa Kreatif)

Guru menekankan dan menciptakan persepsi siswa bahwa keberhasilan individu ditentukan oleh keberhasilan kelompok mereka.

5. Team Study (Belajar Tim)

Siswa belajar menggunakan lembar kerja siswa, guru memberikan bimbingan kepada siswa yang membutuhkan bantuan secara individual. Siswa yang memiliki catatan akademik yang baik diminta untuk membantu anggota yang lain dalam kelompok sebagai tutor sebaya.

6. Fact Test (Tes Fakta)

Guru memberikan tes kecil (kuis) kepada siswa

7. Team Score dan Team Recognition (Penilaian dan Pengakuan Tim)

Langkah berikutnya guru memberikan nilai untuk kinerja kelompok dan memberikan penghargaan terhadap kelompok yang dapat melewati tugas dengan baik. Adapun kelompok yang belum dapat melewati tugas dengan baik, guru tetap mengakui mereka sebagai "Bukan Kelompok Gagal".

8. Whole-Class Units (Penyatuan Pemahaman dalam Kelas)

Langkah terakhir adalah guru menyajikan ulang materi di akhir bagian dengan menggunakan strategi pemecahan masalah untuk setiap siswa dalam kelas. Teknik pengumpulan data yang dilakukan dalam penelitian ini adalah teknik tes, observasi dan dokumentasi. Untuk memperoleh gambaran dari hasil penelitian ini, maka dilakukan analisis data mengenai tingkat aktivitas siswa dan rata-rata hasil belajar siswa. Penilaian aktivitas siswa pada saat menggunakan model pembelajaran kooperatif tipe TAI dituangkan dalam lembar observasi untuk mengetahui aspekaspek yang diteliti. Rata-rata hasil belajar siswa digunakan untuk mengetahui hasil belajar siswa dalam satu kelas dan untuk mengetahui peningkatan hasil belajar dengan membandingkan ratarata skor hasil belajar saat pretest dan posttest.

\section{HASIL DAN PEMBAHASAN}

HASIL

Sebelum melakukan penelitian, peneliti melakukan observasi terhadap nilai fisika siswa pada mata pelajaran sebelumnya yaitu materi suhu dan kalor yang diperoleh dari guru bidang studi sebagai nilai 
Implementasi Model Pembelajaran...

pretest. Nilai ini juga yang dimanfaatkan peneliti sebagai acuan untuk mengelompokkan siswa sebagai kelompok atas dan kelompok bawah yang menjadi dasar dalam pembagian kelompok. Perbandingan data ketuntasan hasil belajar pada pretest dan posttest masing-masing dapat dilihat pada Tabel 1 dan Tabel 2. Data ini menggambarkan ketuntasan hasil belajar sebelum dan sesudah diterapkan model pembelajaran kooperatif tipe TAI dalam pembelajaran materi optika geometris.

Tabel 1. Ketuntasan Belajar Berdasarkan Skor pretest

\begin{tabular}{ccc}
\hline Keterangan & Jumlah & Persentase \\
\hline Tuntas & 3 & $11,11 \%$ \\
\hline Tidak Tuntas & 24 & $88,89 \%$ \\
\hline Tabel 2. Ketuntasan & Belajar Berdasarkan Skor posttest \\
\hline Keterangan & Jumlah & Persentase \\
\hline Tuntas & 22 & $81,48 \%$ \\
\hline Tidak Tuntas & 5 & $18,52 \%$ \\
\hline
\end{tabular}

Perbandingan rata-rata hasil belajar sebelum dan sesudah diterapkan model pembelajaran kooperatif tipe TAI dapat dilihat pada Gambar 1. Data ini juga diperoleh dari hasil pretest dan postest yang telah dilakukan oleh siswa.

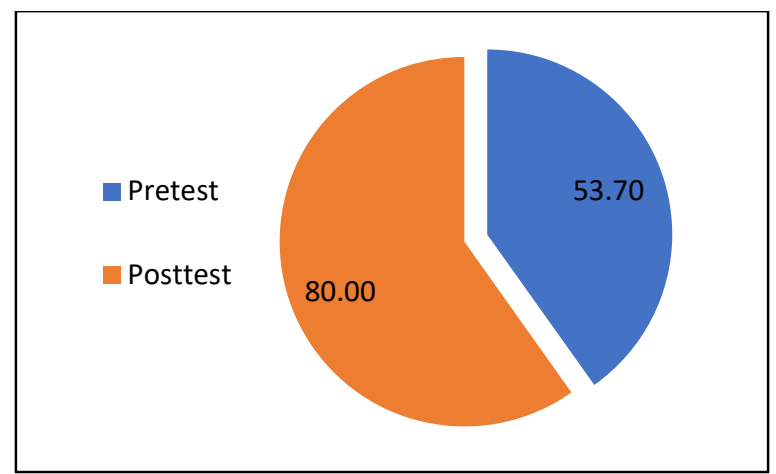

Gambar 1 Diagram rata-rata hasil belajar pada pretest dan posttest

Berdasarkan hasil observasi aktivitas siswa pada saat menggunakan model pembelajaran kooperatif tipe TAI, nilai rata-rata persentase aktivitas siswa adalah sebesar $93,11 \%$ dengan kriteria aktivitas siswa "Sangat Baik". Hasil observasi aktivitas belajar siswa siklus I dapat dilihat pada Tabel 3 dan hasil observasi aktivitas belajar siswa siklus II dapat dilihat pada table 4.

Tabel 3. Distribusi nilai aktivitas belajar siswa siklus I

\begin{tabular}{ccc}
\hline Kategori & $\begin{array}{c}\text { Jumlah } \\
\text { Siswa }\end{array}$ & Persentase \\
\hline Sangat Baik & 3 & $11,11 \%$ \\
\hline Baik & 15 & $55,56 \%$ \\
\hline Cukup & 6 & $22,22 \%$ \\
\hline Kurang & 1 & $3,70 \%$ \\
\hline Sangat Kurang & 2 & $7,41 \%$ \\
\hline
\end{tabular}

Tabel 4. Distribusi nilai aktivitas belajar siswa siklus II

\begin{tabular}{ccc}
\hline Kategori & $\begin{array}{c}\text { Jumlah } \\
\text { Siswa }\end{array}$ & Persentase \\
\hline Sangat Baik & 20 & $74,07 \%$ \\
\hline Baik & 7 & $25,93 \%$ \\
\hline Cukup & 0 & $0 \%$ \\
\hline Kurang & 0 & $0 \%$ \\
\hline Sangat Kurang & 0 & $0 \%$ \\
\hline
\end{tabular}


Implementasi Model Pembelajaran...

\section{PEMBAHASAN}

Tabel 1 menunjukkan siswa yang telah mencapai nilai ketuntasan minimal $(\mathrm{KKM}=80)$ sebelum diterapkannya model pembelajaran kooperatif tipe TAl hanya 3 siswa, sedangkan 24 siswa yang dinyatakan belum tuntas. Nilai rata-rata keseluruhan siswa adalah 53,70 (Gambar 1). Data ketuntasan hasil belajar setelah diterapkan model pembelajaran kooperatif tipe TAl dapat dilihat pada Tabel 2. Berdasarkan hasil posttest yang dilakukan setelah diterapkan model pembelajaran kooperatif tipe TAI, diperoleh bahwa 22 siswa mencapai nilai $\geq 80$, dengan kata lain $81,48 \%$ dari total siswa yang telah mencapai ketuntasan pembelajaran. Nilai rata-rata siswa setelah posttest adalah 80 (Gambar 1).

Tabel 2 menunjukkan bahwa jumlah siswa yang tuntas dalam pembelajaran fisika mengalami peningkatan yang sangat signifikan. Selain itu, hasil belajar rata-rata yang diperoleh setelah diterapkan model pembelajaran kooperatif tipe TAI juga meningkat secara signifikan seperti yang terlihat pada Gambar 1. Oleh karena itu dapat dikatakan bahwa pembelajaran tipe TAI lebih efektif dalam meningkatkan hasil belajar siswa. Hasil ini sesuai dengan studi yang dilakukan oleh Wulandari et al. (2020) yang menyatakan bahwa peningkatan hasil belajar dalam penerapan model pembelajaran tipe TAI disebabkan karena keterlibatan siswa secara langsung dalam proses pembelajaran. Kelebihan pembelajaran tipe TAI diantaranya adalah dapat membuat siswa bekerja sama antar kelompok dalam memecahkan masalah, membantu siswa yang kurang mampu secara akademik, meningkatkan pengetahuan siswa, meningkatkan kemampuan untuk menemukan konsep materi pembelajaran, memotivasi siswa dalam belajar kelompok. Adanya kegiatan saling membantu antar anggota dalam kelompok ini memungkinkan peningkatan jumlah siswa yang mencapai ketuntasan belajar dalam kelas.

Tabel 3 menunjukkan bahwa siswa yang termasuk dalam katagori aktivitas belajar "Sangat Baik" sebanyak 3 orang siswa atau dengan persentase sebesar $11,11 \%$, untuk katagori "Baik" sebanyak 15 siswa atau dengan persentase sebesar $55,56 \%$, untuk katagori "Cukup" sebanyak 6 orang atau dengan persentase sebesar 22,22\%. Adapun untuk katagori "Kurang" sebanyak 1 orang atau dengan persentase sebesar $3,70 \%$ dan katagori "Sangat Kurang" sebanyak 2 orang atau dengan persentase sebesar $7,41 \%$. Tabel 4 menunjukkan bahwa siswa yang termasuk dalam kategori aktivitas belajar "Sangat Baik" sebanyak 20 orang siswa atau dengan persentase sebesar 74,07 \% dan untuk katagori "Baik" sebanyak 7 siswa atau dengan persentase sebesar $25,93 \%$.

Secara keseluruhan, aktivitas siswa di kelas selama proses pembelajaran memiliki kriteria baik. Hal ini sesuai dengan hasil penelitian yang dilakukan oleh Fitriyah \& Arief (2017) yang menyatakan bahwa penerapan model pembelajaran Kooperatif tipe TAI membuat siswa menjadi lebih aktif dalam proses pembelajaran. Berdasarkan hal tersebut dapat dikatakan bahwa pembelajaran kooperatif tipe TAI dapat meningkatkan aktivitas siswa untuk terlibat dalam proses pembelajaran. Dalam pemecahan masalah yang diberikan guru, siswa saling berdiskusi dan berkomunikasi untuk memahami setiap konsep. Setiap anggota kelompok dapat bekerja pada satu masalah sebagai bentuk tanggung jawab bersama. Penerapan model pembelajaran kooperatif tipe TAI memberikan penekanan lebih pada penghargaan kelompok, tanggung jawab individu, dan kesempatan yang sama untuk berbagi hasil kepada setiap anggota kelompok. Sebagian besar siswa juga mengakui bahwa penerapan model pembelajaran yang menekankan pemanfaatan kelompok siswa, masalah yang sulit akan lebih mudah untuk dipecahkan. $\mathrm{Hal}$ ini disebabkan karena prinsip-prinsip yang harus ditegakkan terkait dengan kelompok kooperatif dimana setiap siswa dalam kelompok harus memiliki tingkat kemampuan yang heterogen (tinggi, menengah, dan rendah) dan mengacu pada berbagai metode pengajaran di mana siswa bekerja dalam sebuah kelompok kecil untuk saling membantu dalam mempelajari materi. Sebagai tambahan, pelaksanaan model pembelajaran kooperatif tipe TAI mengharuskan siswa untuk menuliskan langkahlangkah pemecahan masalah secara rinci. Oleh karena itu, siswa perlu berkomunikasi secara aktif dalam kelompok untuk memahami masalah yang diberikan.

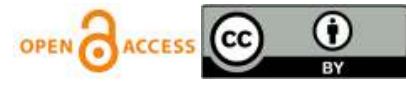


Implementasi Model Pembelajaran...

\section{PENUTUP}

Berdasarkan hasil penetian yang telah dilakukan, maka dapat disimpulkan bahwa penerapan model pembelajaran kooperatif tipe TAI dapat meningkatkan hasil belajar yang dilihat dari hasil pretestposttest siswa. Selain itu model pembelajaran tersebut dapat meningkatkan aktivitas siswa yang dilihat dari hasil observasi dan dokumentasi yang dilakukan selama proses pembelajaran berlangsung.

\section{DAFTAR PUSTAKA}

Cahyaningsih, U (2019). Penerapan model pembelajaran kooperatif tipe TAl (team assisted individualization) untuk meningkatkan hasil belajar siswa pada mata pelajaran matematika. Jurnal Cakrawala Pendas (JCP), 5(1), 45-52.

Fitriyah, A., \& Arief, A. (2017). Penerapan model pembelajaran kooperatif tipe TAl (team assisted individualization) untuk meningkatkan aktivitas dan hasil belajar siswa kelas $\mathrm{X}$ pada pokok bahasan momentum dan impuls di MAN Mojosari Mojokerto. Jurnal Inovasi Pendidikan Fisika (JIPF), 6(3), 153-156.

Huda, M. (2012). Cooperatif learning: metode, teknik, stuktur dan model penerapan. Yogyakarta: Pustaka Belajar.

Soetjipt \& Sumarmi. (2017). Improving the students' activity and learning outcomes on social sciences subject using round table and rally coach of cooperative learning model. Journal of Education and Practice, 8(11), 30-37.

Mardhiah, A (2016). Penerapan model pembelajaran kooperatif tipe TAl (team assisted individualization) untuk meningkatkan prestasi belajar siswa pada materi konduktor dan isolator panas. Lentera, 16(19), 98-105

Megawatai, Y. D. N., \& Sari, A. R. (2012). Model pembelajaran kooperatif tipe teams assisted individualization (TAI) dalam meningkatkan keaktifan siswa dan hasil belajar akutansi siswa kelas XI IPS 1 SMA Negeri 1 Banjarnegara tahun ajaran 2011/2012. Jurnal Pendidikan Akuntansi Indonesia. 10(1), 162-180.

Permatasari, H (2012). Penerapan model pembelajaran kooperatif tipe TAl (team assisted individualization) untuk meningkatkan hasil belajar akuntansi siswa. Universitas Negeri Yogyakarta (UNY). 107-108.

Rudi, L. (2017). Application of teaching model of team assisted individualization (TAl) in basic chemistry courses in students of forestry and science of environmental Universitas Halu Oleo, International Journal of Education and Research, 5(11), 69-76.

Rusman. (2011). Seri manajemen sekolah bermutu model-model pembelajaran mengembangkan profesional guru. Jakarta: Rajagrafindo Persada.

Slavin, R. E. 2011. Cooperative Learning Toeri Riset Dan Praktik. Bandung: Nusa Media.

Sudjana, N. (2009). Penilaian hasil proses belajar mengajar. Bandung: Remaja Rosdakarya.

Sudjana, N. (2010). Dasar-dasar proses belajar mengajar. Bandung: Remaja Rosdakarya. 
Implementasi Model Pembelajaran...

Sutrisno, V. L. P., \& Siswanto, B. T. (2016). Faktor-faktor yang mempengaruhi hasil belajar siswa pada pembelajaran praktik kelistrikan otomotif SMK di kota Yogyakarta. Jurnal Pendidikan Vokasi, $6(1), 111-120$.

Valery, R., Nofriansyah. (2018). Cooperative learning in the learning activity of students, International Journal of Scientific and Research Publication, 8(9), 62-72.

Wulandari, L., Widodo, J., \& Sulhadi. (2020). The implementation of learning instrument of soil forming material with cooperative model type of team assisted individualization of elementary school students. Journal of Primary Education, 9(1), 120-128. 